\title{
Public interest litigation and the civil society factor
}

\author{
Harriet Samuels* \\ Westminster Law School, University of Westminster, London, UK \\ *Author email: H.samuels@westminster.ac.uk
}

(Accepted 13 May 2018)

\begin{abstract}
This article explores civil society organisations' (CSOs) participation in judicial review proceedings. This became contentious when the Ministry of Justice announced that it intended to reform the judicial review process, and suggested changes to the law on standing and third-party interventions. Ultimately, the Criminal Justice and Courts Act 2015 did not amend the law in these areas, but has arguably made it more difficult for CSOs to engage in public interest litigation. Attempts to restrict the access of CSOs to judicial review need to be seen in the context of the shifting relationship between CSOs and the state, and differing perspectives on their function. If CSOs are to continue to take part in judicial review cases they need to justify their presence in terms of their expertise and on the ground knowledge. It is argued that deliberative, dignitarian and more general theories about the nature of civil society may well establish a basis for CSOs' continued presence in judicial review litigation.
\end{abstract}

Keywords: public interest litigation; civil society organisations; judicial review

\section{Introduction}

The legal climate is becoming increasingly chilly towards public interest litigation (PIL). The gaps in legal services consequent upon the reductions in legal aid and the changes to the judicial review procedure, made by the Criminal Justice and Courts Act 2015, make it more difficult to conduct PIL. Those sceptical of the value of PIL characterise it as a form of political lobbying inappropriate in the courtroom. By contrast, civil society organisations (CSOs) value the chance to be part of the judicial review process. ${ }^{1}$ This is apparent from CSOs' resistance to suggestions in the Ministry of Justice's consultation paper Judicial Review: Proposals for Further Reform (Proposals for Further Reform) that the rules on standing and third-party interventions be tightened, thus making judicial review less accessible. ${ }^{2}$

CSOs, alongside the legal profession and judges, cite the key components of the rule of law (namely accountability and legality) as justification for CSOs' involvement in judicial review. It is axiomatic that a sound legal claim is integral to any successful litigation. Another importunate argument, and the one

\footnotetext{
${ }^{1}$ Groups involved in PIL can be classified, and referred to variously. The term civil society organisation is used rather than pressure or interest group, third sector, non-government organisations (NGOs) or social movement. CSO is the term used since 2010 by government. See Cabinet Office The Compact: The Coalition Government and Civil Society Organisations Working Effectively in Partnership for the Benefit of Communities and Citizens in England (Cabinet Office, 2010) p 6 (hereafter The Compact 2010). CSOs are characterised as being not for profit, self-governing, independent of government and acting for a public benefit. See J Kendall 'The UK ingredients in a hyperactive policy environment' in J Kendall (ed) Handbook on Third Sector Policy in Europe: Multi-Level Processes and Organised Civil Society (Cheltenham: Edward Elgar, 2009) p 72. See also J Kendall and M Knapp 'A loose and baggy monster: boundaries, definition and typologies' in J Davis Smith, C Rochester and R Hedley (eds) An Introduction to the Voluntary Sector (London: Routledge, 1995) p 65.

${ }^{2}$ Ministry of Justice Judicial Review: Proposals for Further Reform Cm 8703 (London: TSO, 2013).

(C) The Society of Legal Scholars 2018. This is an Open Access article, distributed under the terms of the Creative Commons Attribution licence (http://creativecommons.org/licenses/by/4.0/), which permits unrestricted re-use, distribution, and reproduction in any medium, provided the original work is properly cited.
} 
focused on here, is that CSOs' presence in judicial review proceedings provides an opportunity for their participation and for holding government to account. CSOs are a counterbalance to the power of the state and act as a voice for those whose interest might otherwise be sidelined.

CSOs have perceived government initiatives to limit their access to judicial review proceedings as part of a pattern of law and policies that inhibit their advocacy work. A report commissioned by the National Council for Voluntary Organisations (NCVO), an umbrella body representing many mainstream CSOs, stated that:

When we heard that Iain Duncan Smith had attacked the Child Poverty Action Group (CPAG) in 2011 we thought it might have been an aberration. He said that the CPAG's legal challenge to housing benefit reforms was 'ridiculous ... irresponsible behaviour' and said it was a 'massive waste of taxpayers' money and court time'. ${ }^{3}$ Since then Ministers have started to reduce the ability of the voluntary sector to turn to the courts in various ways. ${ }^{4}$

CSOs were perturbed by these and similar comments. What was expressed was not a riposte to the CSOs' allegations of abuse of power. Rather it was a denial of the legitimacy of the CSO's attempt to challenge the government in the courts. This is troubling for CSOs, who facilitate both political and legal accountability by feeding through information, offering insights from their work and mobilising those affected by law and policy.

Many CSOs see themselves as having a responsibility to assist those who lack sufficient knowledge and funds to identify and pursue abuses of power. The number of judicial review claims brought by CSOs is relatively small, but they have been involved in some significant legal challenges to government policies, either as claimants or interveners. ${ }^{5}$ This is particularly true of CSOs who provide services in areas such as welfare, housing, immigration, prisoners' rights and community care. CSOs mostly use political avenues to advance their agendas by joining debates on policy, working with civil servants, parliamentary bodies and other political mechanisms. ${ }^{6}$ CSOs may also engage with law to prevent executive excess or where courts are making significant interpretations or developing the law in areas within their remit. They facilitate legal accountability, which includes not only the protection of rights and challenging the abuse of power, but also participation and the communication of values and principles. ${ }^{7}$ The Supreme Court, albeit it in different circumstances, has recently reiterated the importance of access to the courts; one reason given was that judicial decisions often determine issues of general public importance, and are not just of value to the parties to the case. ${ }^{8}$

This paper examines the impact that the changing relationship between the state and civil society has had on the dispute over PIL. The first part discusses the background to the current debate on PIL and the scope of judicial review. The second part looks more closely at the reasons given by CSOs for wanting to take part in judicial review claims, as put forward in their responses to the Proposals for Further Reform consultation and other CSO' produced materials. The third part of the paper reflects on the justification for access to the courts demanded by civil society. It contributes to the existing scholarship by analysing how measures taken to constrain CSO activities in the political realm have led to a questioning of their advocacy and participation in judicial review cases. It also adds to the

\footnotetext{
${ }^{3} \mathrm{R}$ Ramesh 'Iain Duncan Smith accused of “losing his cool” in housing benefit outburst' (The Guardian, 14 October 2011).

${ }^{4}$ The Panel on the Independence of the Voluntary Sector Independence Undervalued: The Voluntary Sector in 2014, The Panel's Third Annual Assessment (London: The Baring Foundation, 2014) p 27.

${ }^{5}$ See $n 25$ below.

${ }^{6}$ For a discussion of different forms of accountability see D Oliver Constitutional Reform in the UK (Oxford: Oxford University Press, 2003) p 56.

${ }^{7} \mathrm{~J}$ King 'The instrumental value of legal accountability' in N Bamforth and P Leyland (eds) Accountability in the Contemporary Constitution (Oxford: Oxford University Press, 2013) p 125.

${ }^{8} R$ (on the application of Unison) $v$ Lord Chancellor [2015] UKSC 51 at para 69.
} 
debate on PIL by taking a fresh look at deliberative and dignitarian justifications for PIL. It builds a stronger conceptual framework by situating them within notions of civil society that regard the autonomy and distinctiveness of CSOs as imperative in enabling them to speak truth to power. It maintains that unless CSOs retain their independence, and make the normative case for PIL, there is the real possibility that this option will be removed by stealth, and legal accountability will be permanently weakened.

This discussion of PIL is not intended as a 'call to arms' to CSOs to make claims or to intervene in judicial review cases. There are difficult strategic decisions to be made in terms of costs, unwanted publicity, and decisions that may provide unhelpful precedents for the future. ${ }^{9}$ The limitations of PIL are well known and have been examined across various disciplines. ${ }^{10}$ They include doubts about the effectiveness of PIL in bringing about long-term social change. ${ }^{11}$ There is also the possibility that only those groups who are well funded and regularly participate in legal processes as 'repeat players' are likely to be successful, thus reinforcing existing hierarchies. ${ }^{12}$ Other misgivings are that it distracts from political activities, undermines the neutrality of the judiciary and requires the court to make polycentric decisions better made elsewhere. ${ }^{13}$ The more practical limitations of PIL include costs, bad publicity and obtaining a pyrrhic victory that will be quickly overturned by a public authority or by legislation. ${ }^{14}$ Recently the Charity Commission has issued guidelines on litigation warning of the need to carefully balance risks when bringing test cases. ${ }^{15}$ These dilemmas are not new, and are matters for a CSO to weigh up when it decides whether or not it wants to become involved in legal proceedings.

Access to the courts is of critical importance to CSOs, despite the risks, and alternative sources of finance, such as crowdsourcing, are being used to overcome funding difficulties. ${ }^{16}$ There is also ongoing research into the effective use of law in the work of the voluntary sector. ${ }^{17}$ The fire in a tower block in London, owned by a local authority, killing 71 residents in June 2017, drew attention to the difficulties of ordinary citizens in challenging public authorities. The Grenfell Tower Association claimed they were unable to obtain legal advice to explore legal remedies over safety issues, before the fire. ${ }^{18}$ At the same time, the constitution is being re-shaped as the UK leaves the EU and there is uncertainty about the future of the Human Rights Act (HRA). The litigation in $R$ (on the application of Miller) $v$ Secretary of State for the European Union has drawn attention to the power of the courts on judicial review. ${ }^{19}$ In this atmosphere, it is likely that the role of PIL in the constitution is going to remain controversial. This is significant for organisations engaging in PIL and it is important that the issues surrounding their presence are fully explored.

\footnotetext{
${ }^{9}$ See further J Leslie and M Spurrier 'A best practice guide to strategic litigation - part 1' (2013) November LAG 7; J Leslie and M Spurrier 'A best practice guide to strategic litigation - part 2' (2014) May LAG 3.

${ }^{10}$ See C Hilson 'The courts and social movements: two literatures and two methodologies, mobilising ideas' 18 February 2013, available at https://mobilizingideas.wordpress.com/2013/02/18/the-courts-and-social-movements-two-literatures-andtwo-methodologies/ (last accessed 12 July 2018).

${ }^{11}$ GN Rosenberg The Hollow Hope: Can Courts Bring About Social Change? (Chicago: University of Chicago Press, 1991). See contra M McCann Rights at Work: Pay Equity Reform and the Politics of Legal Mobilisation (Chicago: University of Chicago Press, 1994) and D Schultz Leveraging the Law: Using the Courts to Achieve Social Change (New York: Peter Lang, 1998).

${ }^{12}$ M Galantar 'Why the "haves" come out ahead: speculation on the limits of legal change' (1974) Law and Society Review 95.

${ }^{13} \mathrm{C}$ Harlow and R Rawlings Pressure through Law (London: Routledge, 1992).

${ }^{14}$ Leslie and Spurrier, above $\mathrm{n} 9$.

${ }^{15}$ The Charity Commission Charities and Litigation: The Legal Underpinnings August 2016.

${ }^{16}$ See Crowdjustice, available at https://www.crowdjustice.co.uk/cases/ (last accessed 12 June 2018). See P McCurry 'Crowdfunding catches on to judicial reviews' (2016) Nov/Dec Third Sector 63.

${ }^{17}$ Baring Foundation and the Legal Education Foundation Programme on Strengthening the Voluntary Sector, https://baring foundation.org.uk/programme/strengthening-the-voluntary-sector-programme/ (last accessed 12 June 2018).

${ }^{18} \mathrm{O}$ Bowcott 'Legal aid cuts "may have stopped Grenfell tenants pursuing safety concerns"' (The Guardian, 29 June 2017).

${ }^{19}$ [2017] UKSC 5.
} 


\section{Civil society organisations and public interest litigation: when opportunity knocks}

PIL refers to the activity of using litigation to obtain wider collective objectives that go beyond the interest of the parties to the case. ${ }^{20}$ Bringing test cases, challenging the decisions of public authorities and third-party interventions are the most common forms of PIL. PIL can involve a group bringing a case in their own name or seeking out and/or supporting those who want to litigate in cases that have a broader impact. Some definitions of PIL require that the activities directly relate to advancing the causes of minority groups. ${ }^{21}$ Generally, it will involve a group asking the court to reconsider a past decision, decide an issue that will affect a large group or particular class of people, or consider a new legal point or perspective. PIL takes many forms and extends across different areas of law, with employment and tort law being popular sites of PIL. The focus here is on judicial review because it is the most regularly used forum for challenging public authorities, and the legitimacy of this activity has been called into question.

There is a long-standing tradition of PIL in the UK and within judicial review proceedings. ${ }^{22}$ It was, therefore, to be expected that aspects of the legislation and policy implementing the austerity agenda and the subsequent cuts in public expenditure, introduced by the Coalition Government (2010-2015), to address the deficit, would be tested in the courts. ${ }^{23}$ Consequently, CSOs were involved in challenges to key elements of government policies. ${ }^{24}$ For example, the implementation of two of the Coalition's most controversial and highly-publicised welfare law changes were the subject of Supreme Court decisions. Both CPAG and Shelter intervened in the 'benefits cap' case and CPAG acted for the claimants challenging the imposition of the 'bedroom tax' in the case of a family with a disabled child. ${ }^{25}$

The Coalition Government expressed disquiet about PIL and proposed reducing the opportunities that CSOs had to engage in judicial review. This was commensurate with the antipathy some ministers had expressed for PIL, and especially the litigation generated by the HRA. ${ }^{26}$ The ability to engage in PIL is determined by the existence of legal opportunity structures. As Hilson explains, this includes wide rules of standing, rules limiting costs and the availability of in-house lawyers, whilst legal opportunities include judicial receptiveness and actor agency in making use of possibilities. ${ }^{27}$

The Proposals for Further Reform consultation in 2013 stated that judicial review should be reformed to address the 'impact of judicial review on economic recovery and growth' and 'the inappropriate use of judicial review as a campaign tactic'. ${ }^{28}$ It asserted that there was a need to deal with 'the delays and costs associated with judicial review that delayed executive action'. ${ }^{29}$ The consultation proposed a number of changes, but the most far reaching were to narrow the rules on standing and to

\footnotetext{
${ }^{20}$ Harlow and Rawlings, above n 13, p 1.

${ }^{21}$ J Cooper and R Dhavan Public Interest Law (Oxford: Basil Blackwell, 1987) p 5 and T Prosser Test Cases for the Poor: Legal Techniques in the Politics of Social Welfare (London: Child Poverty Action Group, 1983).

${ }^{22}$ Harlow and Rawlings, above n 13, p 291.

${ }^{23}$ See further HM Treasury Spending Review 2010 Cm 7942 (London: TSO, 2010).

${ }^{24}$ T Dyke 'Judicial review in an age of austerity' (2011) JR 202 and L Busch 'Austerity and equality' (2013) JR 6.

${ }^{25} R$ (on the application of SG and Others) (previously JS and Others) $v$ Secretary of State for Work and Pensions [2015] UKSC 16 and $R$ (Rutherford and Todd) $v$ SSWP [2016] UKSC 58. Other examples include $R$ (on the application of the Rights of Women) $v$ Lord Chancellor and Secretary of State for Justice [2016] EWCA Civ 91 and $R$ (on the application of McDonald) v Kensington and Chelsea RLBC (Age UK Intervening) [2011] UKSC 33.

${ }^{26}$ See above $\mathrm{n} 4$ and see further P Munce 'The conservative party and constitutional reform: revisiting the conservative dilemma through Cameron's bill of rights' (2014) Parliamentary Affairs 80.

${ }^{27} \mathrm{C}$ Hilson 'New social movements: the role of legal opportunity' (2002) Journal of European Public Policy 238. See further L Hodson NGOs and the Struggle for Human Rights in Europe (London: Hart, 2010); L Vanhala Making Rights a Reality? Disability Rights Activists and Legal Mobilization (Cambridge: Cambridge University Press, 2011). From a US perspective see E Andersen Out of the Closet and into the Courts, Legal Opportunity Structure and Gay Rights Litigation (Michigan: University of Michigan Press, 2005).

${ }^{28}$ Proposals for Further Reform, above n 2, paras 7-9. See also Ministry of Justice Judicial Review: Proposals for Reform Cm 8515 (London: TSO, 2012). See the Civil Procedure (Amendment Rules No 4) Rules 2013. See further V Bondy and M Sunkin 'Judicial review reform: who is afraid of judicial review: debunking the myth of growth and abuse' UK Constitutional Law Blog (10 January 2013), available at http://ukconstitutionallaw.org (last accessed 13 June 2018).

${ }^{29}$ Proposals for Further Reform, above n 2, para 7.
} 
restrict third-party interventions. ${ }^{30}$ With regard to standing, its concern was that the 'sufficient interest test' was too broad. ${ }^{31}$ It stated that the executive and Parliament's right to determine the public interest was being challenged, efficient decision making was hindered and cases were being brought by CSOs and others to obtain publicity. ${ }^{32}$ To rectify this, the Government suggested narrowing the rules to 'exclude persons who had only a political or theoretical interest, such as campaigning groups'. ${ }^{33}$ The consultation acknowledged that third-party interventions might be helpful, but that they can also over-complicate proceedings. ${ }^{34}$ For CSOs third-party interventions have been an especially useful method of participation in HRA cases where standing is restricted by the 'victim' test, which precludes them bringing direct claims in the public interest. ${ }^{35}$ The former Minister for Justice put his reasons for making these changes rather more colourfully in an article in the Daily Mail. He complained that '... pressure groups were wasting taxpayers' money and damaging economic progress' by bringing cases that caused delay to government projects. He concluded that judicial review should not be there as 'a promotional tool for countless left-wing campaigners'. ${ }^{36}$

Ultimately, the Government decided against changing the law on standing and third-party interventions. ${ }^{37}$ Instead the law has made it more financially risky for CSOs to bring judicial review claims. ${ }^{38}$ The Criminal Justice and Courts Act 2015 has put the rules on cost capping orders into statutory form and has made them, along with legal aid, unavailable until after the permission stage. $^{39}$ It has put third-party intervenors at risk of having to pay costs and has made it easier for the court to refuse a remedy to a successful claimant. ${ }^{40}$ It has demanded that claimants make known those who help to fund a claim, and has exposed those who may financially support a judicial review to the possibility of paying costs. ${ }^{41}$ The cuts in the availability of legal aid made in the Legal Aid Sentencing and Punishment of Offenders Act 2012 also mean there are reduced funds available. These changes are still bedding down and there is limited evidence available on their impact. ${ }^{42}$ But there is increasing concern about the unaffordability and inaccessibility of judicial review. ${ }^{43}$ CSOs continue to

\footnotetext{
${ }^{30}$ Environmental law and planning cases raise specialist issues in relation to the application of the Aarhus Convention, United Nations Convention on Access to Information, Public Participation in Decision-making and Access to Justice in Environmental Matters (Aarhus, 25 June 1998). These matters are not dealt with in any depth here.

${ }^{31}$ See the Senior Courts Act 1981, s 31(3) and $R v$ National Revenue Commissioners, ex $p$ National Federation of Self Employed and Small Businesses Ltd [1982] AC 617.

${ }^{32}$ Proposals for Further Reform, above n 2, para 79. For cases where CSOs have been granted standing see $R v$ Inspectorate of Pollution, ex $p$ Greenpeace Ltd (No 2) [1994] 4 All ER 329 and $R v$ Secretary of State for Social Services, ex $p$ Child Poverty Action Group [1990] 2 QB 540. Where a CSO was refused standing see $R v$ Secretary of State for the Environment, ex $p$ Rose Theatre Trust Co [1990] 1 QB 504. On standing generally see AXA General Insurance Ltd and Others $v$ Lord Advocate and Others [2011] UKSC 46. See further P Cane 'Standing up for the public' (1995) PL 277 and Proposals for Further Reform, above n 2, para 68 .

${ }^{33}$ Proposals for Further Reform, above n 2, para 80.

${ }^{34}$ Proposals for Further Reform, above n 2, para 90.

${ }^{35}$ HRA 1998, s 7.

${ }^{36} \mathrm{C}$ Grayling 'The judicial review system is not a promotional tool for countless left wing campaigners' (Daily Mail, 11 September 2013).

${ }^{37}$ Ministry of Justice Judicial Review-Proposals for Further Reform: The Government Response Cm 8811 (London: TSO, 2014) p 11.

${ }^{38}$ Criminal Justice and Courts Act 2015, ss 84-90. For an overview see Bingham Centre for the Rule of Law, Public Law Project and Justice Judicial Review and the Rule of Law: An Introduction to the Criminal Justice and Courts Act 2015, Part 4 (London: Bingham Centre for the Rule of Law, Justice and the Public Law Project, 2015), available at http://www.biicl.org/ documents/767_judicial_review_and_the_rule_of_law_-_final_for_web_19_oct_2015.pdf?showdocument=1 (last accessed 13 June 2018).

${ }^{39}$ Criminal Justice and Courts Act 2015, ss 84-90; Civil Procedure (Amendment No 2) Rules 2016, SI 2016/707 and Civil Legal Aid (Remuneration) (Amendment) (No 3) Regulations 2014, SI 2014/607.

${ }^{40}$ Criminal Justice and Courts Act 2015, s 87 and s 54.

${ }^{41}$ Criminal Justice and Courts Act 2015, ss 85-86.

${ }^{42}$ See further A Wallace 'No substantial difference test' (2017) JR 269.

${ }^{43}$ T Hickman 'Public law's disgrace' UK Constitutional Law Blog (9 February 2017), available at https://ukconstitutionallaw.org (last accessed 12 July 2018). See also the concerns expressed by Civil Exchange on changes to the costs rules for environmental
} 
worry that advocacy work is being discouraged, and fear that there is a deliberate attempt to steer them from away from using the courts. ${ }^{44}$

Overall, the de facto impact of these changes to judicial review are to reduce the legal opportunity structures for PIL. The connection made by the government between PIL and the work of CSOs is revelatory and epitomises the tension between them. CSOs see exiling them from the judicial review process as an attempt to clip their wings and inhibit their advocacy work, thus raising issues about their participation in court proceedings. The danger is that changes initiated to inhibit opposition to government decision-making, through the courts, may lead to a longer term weakening of CSOs' capacity to advocate for their clients and hold government to account.

\section{Shifting boundaries: CSOs and the state}

CSOs have established a place within the litigation process encouraged by favourable legal opportunities and broader contemporary norms that have endorsed their contribution to the legal discourse. The judiciary's response to the Proposals for Further Reform consultation was broadly supportive of the current rules on standing and third-party interventions, noting that there was no observable problem with judicial review being misused for campaigning. ${ }^{45}$ The government consultation also observed that the cases identified as being lodged by CSOs 'tended to be relatively successful compared to other JR hearings' ${ }^{46}$ In addition, Bondy, Platt and Sunkin's research sample found only 3\% of judicial reviews were brought directly by interest groups. ${ }^{47}$ This suggests that CSOs have used the courts sparingly, but where they have engaged in court-based litigation, it has usually had a credible legal foundation. With this in mind it is suggested that the government's unease towards PIL is symptomatic of the shift in the relationship between CSOs and the state that took place after 2010. It is this rather than any misuse of judicial review by CSOs that has driven the modifications. It is instructive to reflect on the government's changing expectations and its underlying philosophy towards CSOs, as well as the shifts in the policy environment brought about by the austerity agenda. Understanding this background allows for a more discerning appraisal of the legitimacy of CSOs' involvement in judicial review cases.

The creation of the Coalition Government in 2010 prompted a resetting of the relationship between government and CSOs. This is not unusual, as most governments have reconfigured their relations with civil society to fit their own agendas. ${ }^{48}$ In an oft-cited quote, civil society has been defined as 'the space of un-coerced human association and also the set of relational networks formed for the sake of family, faith, interest and ideology that fill this space'. ${ }^{49}$ It is an understatement to note that there are a myriad of versions and political traditions that accompany the concept of civil society. ${ }^{50}$ One vision of civil society sees the public sphere and civil society as a site of rational deliberation, where real life experiences connect with political forces and institutions providing for participation

\footnotetext{
law cases: Civil Exchange A Shared Society? The Independence of the Voluntary Sector in 2017 (London: Civil Exchange and the Baring Foundation, 2017) p 46.

${ }^{44}$ Civil Exchange 2017, ibid, p 14.

${ }^{45}$ Judiciary of England and Wales Response of the Senior Judiciary to the Ministry of Justice's Consultation Entitled 'Judicial Review: Proposals for Further Reform' (1 November 2013) para 19. See also Lady Hale's positive comments on the role of CSOs: B Hale 'Who guards the guardians?' (2014) Cambridge Journal of International and Comparative Law 100 at 104-105.

${ }^{46}$ Proposals for Further Reform, above n 2, para 78.

${ }^{47} \mathrm{CSO}$ may also support claims by individual claimants that have a wider public interest. These cases are harder to quantify, but the authors conclude that the relatively small number of such cases did not indicate abuse of the system: V Bondy, L Platt and M Sunkin The Value and Effects of Judicial Review: The Nature of Claims, their Outcomes and Consequences (London: Public Law Project, 2015) pp 18 and 34.

${ }^{48} \mathrm{~J}$ Kendall and M Knapp The Voluntary Sector in the UK (Manchester: Manchester University Press, 1006) p 21.

${ }^{49} \mathrm{M}$ Walzer 'The concept of civil society' in M Walzer (ed) Toward a Global Civil Society (Oxford: Berhahn Books, 2002 ) p 7.

${ }^{50} \mathrm{M}$ Edwards Civil Society (Cambridge: Polity, 3rd edn, 2014) p 9.
} 
and debate and a place where new ideas are nurtured. ${ }^{51}$ New Labour's policy elicited some of these themes, drawing CSO's into a partnership as part of a third sector that saw CSOs as '... neither part of the state nor the private profit-making sector and thus well placed to develop policy and provide services as part of a "third way" politics'. ${ }^{52}$ This was supported by the injection of resources and creation of institutions. ${ }^{53}$ It was formalised by a series of concordats referred to as Compacts, which set down, in some detail, the relationship between civil society and government. ${ }^{54}$

During the subsequent period of the Coalition Government the partnership between government and CSOs continued, but was characterised by increased tensions that seeped into the debate on judicial review. There was a philosophical difference with the previous era. The Conservatives perceived CSO activities in terms of more local or geographical community groups or Burkean 'little platoons' in line with the 'Big Society agenda'. ${ }^{55}$ This was consistent with the traditional neo-Tocquevellian ideas of civil society that stress self-reliance, inculcation of societal values and the benefits of an active citizenry solving problems for themselves with minimal state intervention. ${ }^{56}$ Groups that went beyond service provision and had their own agendas, pursued through political and legal forums, did not fit neatly into the Big Society frame and were seen as straying outside of a more traditional remit. ${ }^{57}$ Such groups, including Shelter, CPAG and Age UK are the type of organisations likely to be engaged in PIL. The Big Society accentuated a commitment to, inter alia, volunteering and encouraging community organising. The Big Society concept did not capture the public imagination to the extent hoped, but much of this ideology still guides the Conservative government's policy towards the voluntary sector. ${ }^{58}$

Significantly, the different philosophy of the post-2010 government manifested itself in a series of public disputes where the legitimacy of voice and advocacy role of the sector was questioned. This was particularly noticeable where there was dissent towards aspects of the austerity policy. The Save the Children and Oxfam campaigns on child poverty, and the public comments of the Trussel Trust which runs food banks were accused of being overtly political, and representing the views of the staff and not the beneficiaries of the charity. ${ }^{59}$ In addition, during the 2015 and 2017 General Elections and the EU referendum campaign in 2016, it was reported that CSOs were inhibited from participating in debates on policy issues such as social care. ${ }^{60}$ There was a fear of transgressing the controversial Transparency of Lobbying, Non Party Campaigning and Trade Union

\footnotetext{
${ }^{51}$ J Habermas Between Facts and Norms (Cambridge: Polity Press, 1992) and JL Cohen and A Arato Civil Society and Political Theory (New Baskerville: MIT Press, 1992). For a more sceptical view of civil society see J Ehrenberg Civil Society: The Critical History of an Idea (New York: New York University Press, 1999).

${ }^{52} \mathrm{P}$ Alcock 'Voluntary action, new labour and the "third sector"' in M Hilton and J Mckay (eds) The Ages of Voluntarism: How We Got to the Big Society (Oxford: Oxford University Press for the British Academy, 2011) p 164.

${ }^{53}$ Ibid, p 166.

${ }^{54}$ Home Office The Compact on Relations between the Government and the Voluntary Sector in England Cm 4100 (London: Home Office, 1998). The Compact was redrafted in 2009. See Cabinet Office The Compact on Relations between Government and the Third Sector in England (London: Cabinet Office, 2009). For the most recent version see The Compact 2010, above $\mathrm{n}$ 1. For a critical analysis see C Rochester Rediscovering Voluntary Action (London: Palgrave MacMillan 2013) especially ch 5 and pp 73-84. The Compact is not legally enforceable, but it has been referred to as a model of good practice in various judgments. See $R$ (on the application of Rotao Rahman) v Birmingham City Council [2011] EWHC 944 (Admin).

${ }^{55} \mathrm{M}$ Hilton et al The Politics of Expertise: How NGOs Shaped Modern Britain (Oxford: Oxford University Press, 2013) p 269.

${ }^{56}$ Edwards, above n 50.

${ }^{57}$ Hilton et al, above n 55, p 265.

${ }^{58}$ T May 'The shared society: Prime Minister's speech to the Charity Commission annual meeting', 19 January 2017, available at https://www.gov.uk/government/speeches/the-shared-society-prime-ministers-speech-at-the-charity-commission-annual-meeting (last accessed 13 June 2018).

${ }^{59} \mathrm{~N}$ Lamb 'Is charity campaigning under threat from the coalition government?' (2014) Voluntary Sector Review 125. The Panel on the Independence of the Voluntary Sector An Independent Mission: The Voluntary Sector in 2015: The Panel's Fourth and Final Annual Assessment (London: The Baring Foundation, 2015) pp 37-41.

${ }^{60}$ A Asthana 'Charities scared to speak out during election campaign' (The Guardian, 31 May 2017).
} 
Administration Act 2014 (the Lobbying Act). ${ }^{61}$ The National Council of Voluntary Organisations has documented the anxiety about the attempts to discourage the advocacy work of CSOs and undermine their autonomy. ${ }^{62}$ Tellingly, it lists the moves towards excluding CSOs from the judicial review process as one of the measures inhibiting them from acting as advocates on behalf of their service users. ${ }^{63}$

The obstacles placed in the path of CSOs, making it more difficult for them to challenge government policy in the political sphere, are mirrored by the restrictions in judicial review cases. This points to a dismissive attitude towards the advocacy work of CSOs. For example, the original proposals for the insertion of anti-lobbying clauses in government grants to CSOs were criticised for potentially preventing CSOs entering into policy discussions in areas relevant to their work. It would have made it more difficult for CSOs to work with ministers, local MPs and inhibited giving evidence to select committees in the House of Commons. ${ }^{64}$ These methods are the stock-in-trade of CSOs working with government on policy that affects their areas of interests, and are also mechanisms holding government to account. Although these proposals were amended, the final version is said to create a 'chilling effect' for CSOs. ${ }^{65}$ This correlates with the changes made to the judicial review process that cause greater uncertainty by exposing CSOs to unpredictable costs. ${ }^{66}$

In sum, the various measures initiated by government represent a shift in the underlying philosophy by which the executive interacts with civil society. There is less appreciation of the advocacy role of CSOs, and for the distinctive attributes they bring to the table. This has not only impacted on the capacity of CSOs to participate in policy making and debate, but has generated doubts about their use of legal tactics in instigating legal proceedings, participating through third-party interventions, and supporting those who find it necessary to engage with law.

\section{Beyond the rule of law: CSOs and the courts}

CSOs recognise the need to have sound legal claims, but they go beyond rule of law arguments to justify their activities in judicial review cases. This is evident in the responses of CSOs to the Proposals for Further Reform consultation, which places a high value on the grounds of voice and representation consistent with broader understandings of legal accountability. They draw on their capacity to present their client group's perspective to the court, their acquired knowledge and expertise and their responsibility as members of civil society within a democracy to act as advocates.

By contrast, and unsurprisingly, the responses of the legal profession and CSOs with a legal focus, such as the Public Law Project, primarily adopt a rule of law approach. ${ }^{67}$ This is consistent with narrower versions of legal accountability that gives pre-eminence to the need to police the legal boundaries of executive power, to protect rights and to challenge illegality in the public interest. ${ }^{68}$ The Public

\footnotetext{
${ }^{61} \mathrm{R}$ Cooney “"Get a backbone” during the election, Bubb urges charity leaders' (2017) Third Sector, available at http://www. thirdsector.co.uk/get-backbone-during-election-bubb-urges-charity-leaders/policy-and-politics/article/1434956 (last accessed 13 June 2018).

${ }^{62}$ The Panel on the Independence of the Voluntary Sector Independence under Threat: The Voluntary Sector 2013 (London: Baring Foundation, 2013); The Panel on the Independence of the Voluntary Sector Independence Undervalued: The Voluntary Sector 2014 (London: Baring Foundation, 2014); The Panel on the Independence of the Voluntary Sector 2015, above n 59 and Civil Exchange Independence in Question: The Voluntary Sector in 2016 (London: Baring Foundation, 2016) and Civil Exchange 2017, above n 43.

${ }^{63}$ The Panel on the Independence of the Voluntary Sector 2014, above n 62, p 29. See also Compact Voice Judicial Review-Proposals for Further Reform: A Response by Compact Voice November 2013, available at http://www.compactvoice. org.uk/sites/default/files/judicial_review_-_consultation_response.pdf (last accessed 13 June 2018).

${ }^{64} \mathrm{P}$ Holbrook 'The government has listened to us on the anti lobbying clause' Third Sector 6 December 2016.

${ }^{65}$ See Civil Exchange 2017, above n 43, p 46.

${ }^{66}$ Civil Exchange 2017, above n 43, p 14.

${ }^{67}$ Public Law Project Public Law Project Response to Judicial Review: Proposals for Further Reform Consultation 1 November 2013, para 13, available at http://www.publiclawproject.org.uk/data/resources/147/PLP_consultation-response_ JR_further_reforms_1_11_13.pdf (last accessed 13 June 2018).

${ }^{68} \mathrm{P}$ Cane 'Understanding judicial review and its impact' in M Hertogh and S Halliday (eds) Judicial Review and its Bureaucratic Impact: International and Interdisciplinary Perspectives (Cambridge: Cambridge University Press, 2009) pp 15, 17.
} 
Law Project explains that the government's proposals, to amend the rules on standing and third-party interventions, 'misunderstands the constitutional role of the court'. ${ }^{69}$ Their comments are repeated in many of the other CSO responses. They insist that judicial review is not only about the vindication of individual rights, but is also a means to prevent the abuse of power. ${ }^{70}$ Therefore interested citizens and CSOs must have the ability to challenge government in the courts. ${ }^{71}$

The Government's summary of the responses to the Proposals for Further Reform consultation reports the rule of law grounds, but ignores other reasons given by CSOs for supporting the current law on standing and third-party interventions. ${ }^{72}$ The summary acknowledges that the majority of answers were against any change. ${ }^{73}$ It lists the reasons given, which included some government acts becoming unchallengeable because no-one is directly affected, lack of evidence of problems with the current law, a denial of access to justice and a weakening of the rule of law. ${ }^{74}$ The summary did not report any answers raising the issue of voice and representation, although it mentioned responses that claimed NGOs who made third-party interventions helped the court contextualise public policy thus also benefiting the government. ${ }^{75}$

Conversely, a closer reading of CSOs' responses and the materials produced by the voluntary sector, with less of a legal mandate, reveal a different emphasis. This centres on the CSOs' need to represent their often vulnerable and marginalised service users and on their expertise. ${ }^{76}$ On one level, the pragmatic benefits of group rather than individual challenges are stressed. On another level, the arguments focus on principles that understand CSOs as having a legitimate function in representing a particular group and providing them with a voice. The response of Sense, a charity that works with deaf and blind people, typifies points made by other CSOs. Their reasons for engaging in judicial review are summed up below:

We have had to intervene because people we represent are too marginalised to challenge unlawful acts on their own behalf. In addition, there are some circumstances where an unlawful decision will go unchecked by the fact that there is no individual or organisation that is able to establish sufficient standing to challenge the decision. ${ }^{77}$

Sense and others go on to state that it is convenient for a CSO to bring a single case testing the law rather than allowing multiple cases to proceed. The Public Law Project also makes this point, referring to examples where an unlawful policy has not yet affected any individual or where a significant legal point fails to reach the courts because the defendant 'buys off claimants through settlements. ${ }^{78}$ The

\footnotetext{
${ }^{69}$ Public Law Project, above n 67.

${ }^{70}$ Ibid, para 13. See Sedley LJ in $R v$ Somerset County Council, ex p Dixon (1998) 75 P \& C R 175 at 183.

${ }^{71}$ For an extra judicial discussion see S Sedley 'Not in the public interest' (2014) London Review of Books 29. See contra TRS Allan Constitutional Justice a Liberal Theory of the Rule of Law (Oxford: Oxford University Press, 2001) pp 195-196.

${ }^{72}$ Out of the 325 responses, 242 answered the questions on standing and interventions (questions 9-11): Ministry of Justice 2014, above n 37, p 27.

${ }^{73}$ There were 16 responses in favour of narrowing the law on standing, and 12 that gave a mixed response. The main reasons in favour of a revised test were to protect local authority resources. It was also stated that allowing any person to challenge a decision of a public authority might undermine the democratic process: Ministry of Justice 2014, above n $37, \mathrm{p} 28$.

${ }^{74}$ Ministry of Justice 2014, above n 37, pp 27-28.

${ }^{75}$ Ministry of Justice 2014, above n 37, pp 27-28.

${ }^{76} \mathrm{~A}$ freedom of information request under the Freedom of Information Act 2000, for access to the responses to the consultation, was rejected. The Ministry of Justice provided an excel spreadsheet summarising the individual responses to each question in the consultation (MOJ spreadsheet 2015). Some CSOs provided copies of their responses after a specific request from the author, and others were available on the CSO's website or from other internet sources.

${ }^{77}$ Sense Sense Consultation Response: Judicial Review Proposals for Further Reform 2013, on file with the author.

${ }^{78}$ Public Law Project, above n 67, paras 24 and 25.
} 
submission from Refugee Action notes that CSOs can identify patterns of illegality and by bringing one legal challenge the court can settle the matter. ${ }^{79}$

Further reasons for CSOs participation in judicial review employ a normative approach. This stresses the function of CSOs in communicating the on-the-ground realities of their user groups. For instance, the submission from Sense states that:

Charities like Sense play a critical role as the mouthpiece and representative body for those that have lost their voice or feel that they do not have the strength to fight their own fight. ${ }^{80}$

Another submission from Women's Aid, an organisation that provides a network of services to women who have been subject to domestic violence, makes a similar point:

Women's Aid greatly values the current judicial review system in enabling the voices of women experiencing domestic violence to be heard in cases of public interest ... any changes to the standing for judicial reviews or costs of interveners will impact on charities representing the most vulnerable in society and will cut off their voices from being heard. ${ }^{81}$

Sense and Women's Aid provide cogent arguments for the participation of CSOs in the adjudicatory process that include, but go well beyond, upholding the rule of law. The responses demonstrate that CSOs appreciate the significance of holding government to account through the courts. However, they also want to contribute to judicial decision making by presenting their perspective on the correct interpretation and development of law. This shows that CSOs understand legal accountability as having an expressive element. ${ }^{82}$ By this it is meant that law not only seeks to halt the abuse of power, but also articulates values and principles that determine how the law is interpreted and implemented. ${ }^{83}$ CSOs enrich judicial decision-making by communicating their observations of social reality, thus raising judges' consciousness of how legal principles might play out on the ground. ${ }^{84}$

\section{Justifying CSOs' participation: contemporary perspectives}

The arguments against CSOs participation in PIL are usually based on the perils of politicising the court and jeopardising 'disinterested justice'. ${ }^{85}$ The writing of Morton and Knopff, for instance, in Canada has expressed the view that coalitions of interest groups have captured the judicial process to advance their agenda through judicial activism. They argue that interest groups have achieved legal changes using the Canadian Charter of Rights that would have been difficult to make in the legislature. ${ }^{86}$ This is regarded as an illegitimate bypassing of democratic institutions that privilege elite interests. $^{87}$

The most obvious response is to observe that CSOs work in areas where legal disputes generate controversy. Cases about human rights, equalities, immigration and welfare law engage with issues that attract political interest. CSOs may well have an ongoing political agenda objecting to a policy or practice that subsequently leads to litigation. Provided the claims are grounded in convincing

\footnotetext{
${ }^{79}$ Refugee Action Refugee Action Consultation Response: Ministry of Justice: Judicial Review-Proposals for Further Reform November 2013, on file with the author.

${ }^{80}$ Sense, above n 77.

${ }^{81}$ Women's Aid Women's Aid Consultation Response: Ministry of Justice Consultation on Judicial Review: Proposals for Further Reform October 2013, on file with the author.

${ }^{82}$ King, above n 7, p 146.

${ }^{83}$ Ibid.

${ }^{84}$ See Lady Hale's comments on the valuable insights provided by interventions: Hale, above n 45 .

${ }^{85}$ Harlow and Rawlings, above n 13, p 199.

${ }^{86}$ FL Morton and R Knopff The Charter Revolution and the Court Party (Louisville: Broadview Press, 2000) and I Brodie Friends of the Court: The Privileging of Interest Group Litigants in Canada (New York: State University of New York Press, 2002).

${ }^{87}$ Morton and Knopff, above n 86, p 149.
} 
legal arguments, and abide by the relevant procedural rules, it is hard to justify preventing CSOs from testing the public authority's view of the law, and ensuring that genuine disputes reach the courts. Legislation such as the HRA, and the public sector equalities duty in section 149 of the Equality Act 2010, confers rights and duties that are legally enforceable. The fact that a legal challenge generates publicity in a system that prides itself on open justice and debate should not of itself be a reason for restricting a judicial review. In addition, whether or not a decision is considered judicial overreach is often a matter of dispute, and it is difficult to show the connection between this and CSO activity. ${ }^{88}$

Those who object to the presence of CSOs tend to overstate the sharpness of the divide between law and politics. ${ }^{89}$ They fail to account for the plasticity of public law, particularly human rights law. This is not to suggest that the court's discretion is unconstrained. Rather, it is to agree with Loughlin that the courts are at the interface between law and politics and are required to interpret and apply political ideas within the values and limits of the existing legal structures. ${ }^{90}$

CSOs' claim to enhance the participative and representative character of judicial review proceedings have been supported by deliberative and dignitarian theories. There has, however, been less attention paid by lawyers to theories of civil society that champion the need to protect CSOs' character as autonomous institutions. CSOs are equipped with the knowledge and weight of experience to challenge public authorities, participate in public discourse and facilitate government accountability. By connecting these three frames it is possible to make a stronger case for CSOs' legal work in judicial review cases.

One of the advantages of the deliberative frame is that it sees the court as one of a number of multiple publics where 'door openers' are provided for excluded groups, often represented by CSOs. ${ }^{91}$ This is borne out by the HRA, where litigation is frequently brought by electoral minorities and other marginalised groups. ${ }^{92}$ Rather than the courts thwarting democracy and becoming a surrogate political process, they can shore up democracy and its principles. ${ }^{93}$ Judges, depending on their specific powers, can ensure that executive decisions or legislation has at least taken account of the rights and interests of those who may be sidelined by the executive or Parliament. So, for example, courts having the powers of judicial review of legislation can make certain that legislation has taken account of minorities or unpopular groups that are unable to gain a hearing or lack representation in the legislature. Such groups might include prisoners, travellers, welfare recipients or immigrants. ${ }^{94}$ Others would add an additional requirement that courts review legislation and administrative decisions to ensure they are taken in accordance with key principles and values, for example human rights, and established constitutional norms. ${ }^{95}$

Courts cannot be deliberative in the manner of political and other forums. But broad rules of standing and interventions allow them to be less bipolar and permit a wider range of perspectives to be heard when courts are shaping the law. ${ }^{96}$ This is evidenced by the contribution CSOs have made to the development of human rights law through the number and quality of their interventions. ${ }^{97}$

\footnotetext{
${ }^{88}$ For a contemporary discussion of judicial activism see NW Barber, R Ekins and P Yowell Lord Sumption and the Limits of Law (Oxford: Hart, 2016).

${ }^{89}$ See for example Harlow's warnings about group litigation: C Harlow 'Public law and popular justice' (2002) MLR 1.

${ }^{90} \mathrm{M}$ Loughlin Sword and Scales: An Examination of the Relationship between Law and Politics (Oxford: Hart, 2000$) \mathrm{p} 105$.

${ }^{91}$ A Sathanapally Beyond Disagreement: Open Remedies in Human Rights Adjudication (Oxford: Oxford University Press, 2012) p 66.

${ }^{92}$ A Kavanagh Constitutional Review under the Human Rights Act (Cambridge: Cambridge University Press, 2009) p 379.

${ }^{93}$ Habermas, above n 51 .

${ }^{94}$ J Ely Democracy and Distrust: A Theory of Judicial Review (Cambridge, Mass: Harvard University Press, 1980) and for a variation of this theory see C Sunstein Designing Democracy: What Constitutions Do (Oxford: Oxford University Press, 2001).

${ }^{95}$ Habermas, above $\mathrm{n} \mathrm{51}$, and for a discussion in relation to human rights see S Fredman Human Rights Transformed: Positive Rights and Positive Duties (Oxford: Oxford University Press, 2008).

${ }^{96}$ Fredman ibid, p 107.

${ }^{97} \mathrm{~S}$ Shah, T Poole and M Blackwell 'Rights, interveners and the law lords' (2014) 34 OJLS 295. For a critical view see S Hannett 'Third-party interventions: in the public interest?' (2003) PL 128 and Harlow, above n 89. See contra M Arshi and C O'Cinneide 'Third-party intervention: the public interest reaffirmed' (2004) PL 69.
} 
To cede the space occupied by CSOs would be to make it harder to dispute the interpretation of law adopted by public authorities, in the exercise of their powers and duties, and leave the state less accountable for its decision-making.

There are also compelling arguments based in dignitarian theory for enabling CSOs to participate in PIL. For dignitarian theorists, respecting dignity means understanding people as having the autonomy to regulate their own actions and being able to give an account of themselves that others take seriously. ${ }^{98}$ CSOs ensure that minority positions are heard in legal forums by bringing challenges and intervening in decisions. ${ }^{99}$ Procedures are seen as embodying certain inherent values and are important irrespective of the outcome. These values might include participation, fairness and the protection of dignity. ${ }^{100}$ The point is that the procedures may lead to a better outcome, but this is not their main justification given that sound due process is seen as having an intrinsic value. ${ }^{101}$ Bondy, Platt and Sunkin's research provides support for this view as they found that even claimants who had lost their judicial review claim reported they had achieved non-tangible benefits such as a sense of empowerment. ${ }^{102}$ CSOs' responses in the Proposals for Further Reform consultation put forward instrumental reasons that explained how their presence would improve the final decision. ${ }^{103}$ Yet it is implicit in CSOs' responses that their clients' perspectives on the manner in which laws are being interpreted and applied should be heard and that without their assistance this would not be possible. ${ }^{104}$

The third frame for considering the presence of CSOs connects with dignitarian and deliberative ideas, but draws on the civil society literature. Attacks on the legitimacy of CSOs' presence in court proceedings make this perspective all the more pertinent. As we have seen CSOs view their function in the courtroom as conveying the everyday realities of their constituent groups to the court. But their participation is also a real and symbolic means of respecting the autonomy and independence of CSOs to decide how to pursue their objectives, even if this conflicts with the government's view of their functions or policy. The response of Detention Action makes this point:

Public interest litigation is a vital means for civil society to challenge abusive behaviour by government and public bodies. It is generally recognised that a healthy democracy requires an active civil society with a stake in defining the public interest. All governments risk confusing their own interests with the public interest; this is why scope for scrutiny and challenge is so essential. ${ }^{105}$

Here what is being stressed is the propriety of CSOs' action as part of an active civil society that is entitled to enter public forums, including legal arenas, to speak out for their client group, and where necessary to challenge government.

CSOs' presence in judicial review claims also carries weight because they are repositories of knowledge and experience. It is the expertise of the CSO itself as well as its function of representing others that is accentuated. ${ }^{106}$ CSOs regard themselves as not simply institutions that channel information from the ground, but as having an accumulated knowledge through their own work. They have a

\footnotetext{
${ }^{98} \mathrm{~J}$ Waldron 'How law protects dignity' (2012) CLJ 200 at 201.

${ }^{99}$ See P Bryden 'Public interest intervention in the courts' (1987) Canadian Bar Review 509.

${ }^{100} \mathrm{G}$ Richardson 'The legal regulation of process' in G Richardson and H Genn (eds) Administrative Law and Government Action: The Courts and Alternative Mechanisms of Review (Oxford: Oxford University Press, 1994) p 115.

${ }^{101}$ Richardson, ibid, p 128. For a more sceptical view see DJ Gallighan Due Process and Fair Procedures: A Study of Administrative Procedures (Oxford: Oxford University Press, 1997) p 76 and Harlow and Rawlings Law and Administration (Cambridge: Cambridge University Press, 2009) p 620.

${ }^{102}$ See Bondy, Platt and Sunkin, above n 47, p 37.

${ }^{103}$ See for example Mind's submission reproduced in Mind Legal Unit 'Judicial review: proposals for further reform' (2013) Newsletter 8-12.

${ }^{104}$ See the response of Women's Aid above n 81 and Sense above $\mathrm{n} 77$ to the Proposals for Further Reform Consultation.

${ }^{105}$ Ministry of Justice Spreadsheet 2015, above n 76.

${ }^{106}$ Cane notes that the courts will grant what he calls associational standing where the CSO represents an identifiable group to whom it is accountable. It will grant public interest standing where the CSO claims to represent the public interest in their area of expertise. See Cane, above n 32 .
} 
distinctive voice that is not part of the market or the state. This is recognised by the Compact between government and CSOs which, although diminished in status, remains in force, and includes a commitment by government to consult and to work with CSOs that represent or provide services to under-represented and disadvantaged groups. ${ }^{107}$ The courts also value the competency, respectability and proficiency of CSOs and consider these factors when deciding whether the CSO has a 'sufficient interest' or should be allowed to intervene. ${ }^{108}$ From this perspective there is a need for the law to understand and approve of CSOs as having a special position not just because they can describe the experience of others, but because they are autonomous groups who process empirical knowledge and therefore deserve a hearing.

The involvement of CSOs in judicial review claims also represents an appreciation of the function of CSOs in upholding human rights. CSOs, usually referred to as NGOs, in this context have a history of educating on human rights, standard setting, fact finding and enforcing human rights through the use of judicial and quasi-judicial bodies. ${ }^{109}$ CSOs operationalise human rights values through their work by using human rights to progress their aims and hold public authorities to human rights standards. ${ }^{110}$ This may be by intervening in HRA cases, and supporting individual claimants. It is also done through promoting the use of international human rights instruments and other legislation such as equality laws. ${ }^{111}$ This has been the case with groups that have been involved in service provision and who work in fields involving social and economic rights. Many, but not all, of the cases involving the austerity policy used rights-based arguments to advance their claims. ${ }^{112}$ The criticisms of the HRA in certain sections of the media and government have led to a readiness to undermine the autonomy of CSOs, restricting their access to legal as well as political forums. ${ }^{113}$ This closes off avenues for the redress of grievances that may have enduring consequences affecting the ability of CSOS to help safeguard the rights and interests of different communities.

Supporting CSOs' work is not to overly romanticise their role or to fail to acknowledge the issues of governance, exemplified by the collapse of Kids Company. ${ }^{114}$ It is not to ignore the broader concerns that sometimes arise regarding the disconnect between CSOs and their grassroots when they become closer to government and more professional and managerial in outlook. ${ }^{115}$ These are issues that require CSOs' continual attention. However, there is still evidence that CSOs' experiential knowledge and attachment to particular communities gives them a certain credibility, which has been taken seriously by all governments. It is one of the reasons successive governments have wanted to work with CSOs and have, to varying degrees, drawn them into formal partnerships.

In short, versions of civil society that perceive its task as going beyond volunteering and good works, to verbalise the concerns of its clients, fit with the aims of deliberative and dignitarian theories. CSOs facilitate access, articulate the perspective of their client group and offer their own expertise and understanding to the courts.

\footnotetext{
${ }^{107}$ The Compact 2010, above n 1, para 5.1.

${ }^{108}$ See $R v$ Inspectorate of Pollution, ex $p$ Greenpeace Ltd (No 2), above $\mathrm{n} 32$, and $R v$ Secretary of State for the Foreign and Commonwealth Affairs, ex $p$ World Development Movement Ltd [1995] 1 WLR 386. See Cane, above n 32.

${ }^{109} \mathrm{P}$ Alston and R Goodman International Human Rights: The Successor to International Human Rights in Context (Oxford: Oxford University Press, 2012) pp 1503-1504.

${ }^{110}$ S Calnan The Effectiveness of Domestic Human Rights NGOs: A Comparative Study (Leiden: Martinus Nijhoff, 2008).

${ }^{111}$ See Lady Hale on the role of interveners in drawing the court's attention to international human rights jurisprudence: Hale, above $\mathrm{n} 45$, at 107 .

${ }^{112}$ See for example the reliance on Art 1 Protocol 1 and Art 14 of the European Convention on Human Rights and the United Nations Convention on the Rights of the Child in $R$ (on the application of SG and Others) (previously JS and Others) $v$ Secretary of State for Work and Pensions [2015] UKSC 16, above n 25.

${ }^{113}$ On the hostility to human rights see S Marks 'Backlash: the undeclared war against human rights' (2014) 4 EHRLR 319.

${ }^{114} \mathrm{~J}$ Coleman 'Kids company and beyond' (2015) Solicitors Journal 3.

${ }^{115}$ See Rochester, above n 54. See also A Choudry and D Kapoor (eds) NGOization: Complicity, Contradictions and Prospects (London: Zed Books, 2013).
} 


\section{Conclusion}

The concern about CSOs' use of judicial review is better understood as a general scepticism of their advocacy work. It has been seen as a mission drift away from the more traditional CSO activities of community and philanthropic works. This context prompts greater scrutiny of the claim that CSOs are abusing the judicial review process for cheap publicity, or to deliberately thwart government policy. The CSOs' response to the Proposals for Further Reform consultation demonstrate both pragmatic and normative justifications for their presence in judicial review cases that include, but go beyond, the rule of law reasons of questioning the abuse of power. CSOs' presence in judicial review claims is supported by deliberative and dignitarian theories that seek to explain the value of participation and refute arguments that PIL is anti-democratic.

CSOs are needed to assist claimants navigate the channels left open by the law, and to bring claims in the public interest. To operate effectively they must be able to exercise their judgement independently, and should not be unduly hampered by procedural rules designed to deter their presence in judicial review cases. Reflecting on civil society's function provides insights into its distinctive features and capacities. In the course of heated political debates on austerity, welfare and other issues it is easy for political and legal actors to lose sight of the significance of the structures and processes that support CSOs. Weakening these structures and CSOs' autonomy will have long-term consequences, making it more difficult to hold government to account through the courts and shutting out voices that need to be heard.

Cite this article: Samuels H (2018). Public interest litigation and the civil society factor. Legal Studies 38, 515-528. https:// doi.org/10.1017/lst.2018.9 